\title{
USING FLIPPED CLASSROOM FOR TEACHING PROCEDURAL SKILL IN RESIDENCY SPECIALLY DERMATOLOGY-A SYSTEMATIC REVIEW
}

\author{
Sakina Sadiq, Rahila Yasmeen*, Ayesha Naveed**, Tehseen Naveed***, Sadaf Saleem**** \\ Combined Military Hospital/National University of Medical Sciences (NUMS) Rawalpindi Pakistan, *Riphah International University, Islamabad Pakistan, \\ ${ }^{* *}$ Margallah Institute of Dentistry Rawalpindi Pakistan, ${ }^{* * *}$ Combined Military Hospital Lahore/National University of Medical Sciences (NUMS) Pakistan, \\ ****Pakistan International Medical College, Peshawar Pakistan
}

\begin{abstract}
Objective: To review the available literature investigating effectiveness of flipped classroom (FC) in context to teaching of procedural skills in residency in various medical fields especially in dermatology.

Study Design: Systematic review.

Place and Duration of Study: Flipped classroom meeting out inclusion criteria published in 9 years from 2012 to 2020.

Methodology: Flipped classroom meeting out inclusion criteria published in 9 years from 2012 to 2020 were reviewed by the authors and co-authors as per their feasibility and discussion done by video conferencing by mobile software apps.

Results: To review of 25 full-text articles. Strategic organization of course material, wise choice of pre-class activities, usage of Virtual learning environment, class time utilization tailored to learners needs, adherence to timelines, proper training of staff and proper evaluation; are required for successful implementation of flipped classroom. Students had positive perceptions about this technique.

Conclusion: Flipped classroom is an effective teaching method for procedural skills training in post graduate medical training. Keywords: Flipped classroom, Post graduate trainees, Procedural skills.

This is an Open Access article distributed under the terms of the Creative Commons Attribution License (https://creativecommons.org/licenses/by-nc/4.0/), which permits unrestricted use, distribution, and reproduction in any medium, provided the original work is properly cited.
\end{abstract}

\section{INTRODUCTION}

The post-graduate (PG) training including fellowship programs of our health professionals in different specialties serves as the back bone of our future quality health care system. Exposure to procedural skills in PG training is currently diffuse as it relies on availability of opportunities rather than following pre-designed structured objectives. A good clinical educational environment incorporates PG residents' active involvement, contribution; ensures that both the learning and teaching processes are related to the patients; activates deep learning, encouraging professional intelligence, skill and behavior ${ }^{1}$. Work-life imbalance, peer pressure, burn-outs, career uncertainty, lack of family support, no rewards, sluggish career advancements and institutional policies are the factors negatively effecting the quality of residency training in our settings ${ }^{2}$. Use of flipped classroom (FC) intervention in teaching of residents can help to remove the time and workload barriers in their train-ing and hence improving their competencies and satis-faction with the learning opportunities.

FC intervention can enhance the flexibility of our curriculum especially in COVID-19 pandemic which

Correspondence: Dr Sakina Sadiq, House No. 646, Street No. 75, Sector- 2, Gulshanabad Rawalpindi Pakistan

Received: 26 Aug 2020; revised received: 15 Sep 2020; accepted: 21 Sep 2020 has overwhelmed our health care system, compromising bedside teaching of procedural and behavioral skills to our residents. Its designing principles include; provision of pre-class opportunities for knowledge acquisition to students, motivating students for in-class activity, planning assessment, provision of need based individual guidance by facilitator, adequate time given for assignments, timely feedback by facilitator and availability of accessible technologies for students ${ }^{3}$.

Cognitive load theorymakes the theoretical framework for FC by helping students to make cognitive schemas and thus decreasing cognitive load than traditional face to face training methods ${ }^{4}$. And literature showed FC intervention as an effective method using pre-learning and individual learning pace to decrease the cognitive load ${ }^{5}$. FC for procedural skills has been used in specialties like emergency medicine, gynecology, dentistry, surgery, ophthalmology and dermato$\log y^{6}$. But more work is required to implement this teaching strategy more feasibly and effectively in post graduate medical training.

\section{METHODOLOGY}

Systematic review of selected articles was done by 4 step process of identification, screening, establishing eligibility and final inclusion. Articles shortlisted as per inclusion criteria published from 2012-2020 (9 years) were analyzed in 4 months duration. To review the available literature documenting FC in teaching of 
procedural skills in post graduate medical students especially dermatology.

To find the different pre-class, in-class and assessment strategies for medical procedural skills FC. To find instruments used for recording students perceptions about FC.

Online electronic databases were searched for the purpose of this study i.e. Pub med, ERIC, Psych INFO. In addition, a hand search of the reference lists of identified articles was undertaken and Google Scholar was utilized to identify any other primary sources within After removal of duplicates andgoing through the abstracts, the non-relevant articles were eliminated based on the inclusion and exclusion criteria. Thirty two studies were finally identified as being relevant to the research topic. Full text versions of the articles were obtained, with each article being critically appraised after giving them numerical weightage on the basis of Qualsyst criteria ${ }^{7}$. Any additional relevant literature from a review of the reference lists of each article was scanned. Finally 25 articles were selected for critical appraisal based on good Qualsyst scores. The process of article selection followed the preferred reporting of items for systematic reviews and meta-analyses method. English articles published in peer-reviewed journals from 2012 to 2020 including Original articles and systematic reviews. Articles with literature focus on FC intervention and procedural skills teaching in residency programs. Articles not complying with the inclusion criteria were excluded. Conference papers, opinion papers, letters to editors or editorials or articles not primarily focused on FC or procedural skills but only mentioning it contextually were also excluded.

To avoid selection bias, 2 team members independently reviewed each relevant article, and then all reviewers collectively made the final selection. An iterative process was used to reach consensus. Content analysis of the articles in a step-by-step process was done. The team started with the formulation of the objectives of the study; and reviewing and analyzing the trends and contents of FC research leading to formulation of coding units. Then reviewing of the documents were done again based on application of the coding units. Data were obtained were manually, descriptively analyzed based on the research questions.

The quality assessment tool employed was the QUALSYST7. The tool utilizes two scoring systems for quality assessment, for both quantitative and qualitative research. The score is calculated as sum of ratings of applicable criteria divided by the maximum possible scores of applicable criteria. Based on the scores following articles were finalized for critical appraisal.

\section{RESULTS}

Out of the 26 full text articles reviewed, mostly were quantitative including Randomized control trials, retrospective studies, prospective cohort, case-control, cross-sectional validation studies as well as one metaanalysis. Only 2 studies had mixed-method design and

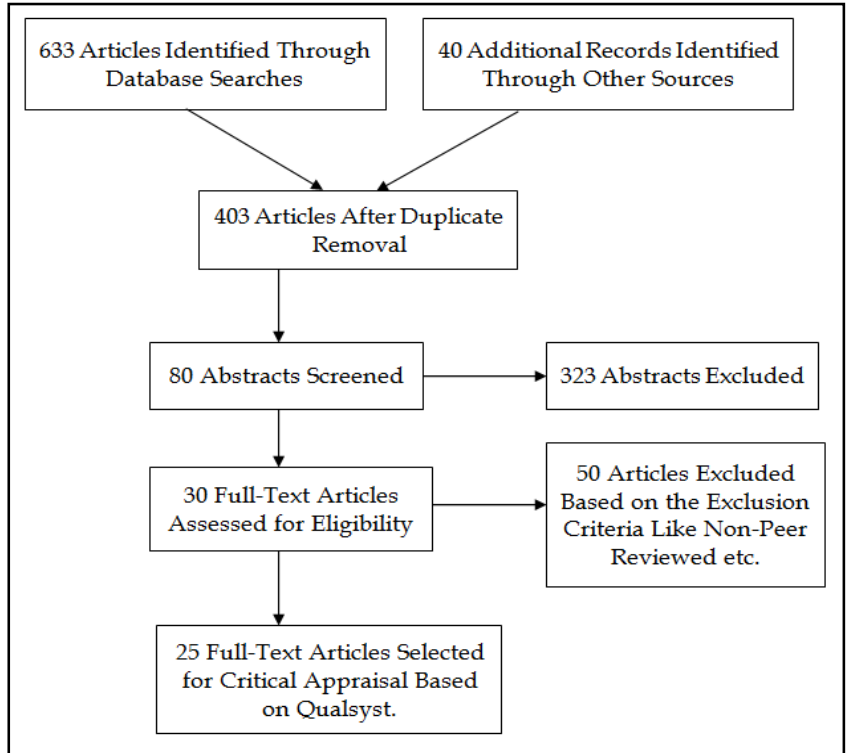

Figure: Flow diagram of the research process.

one was a systematic review ${ }^{19}$. Studies were carried out in different medical/dental/nursing colleges and universities of United States of America, 3 in China, 2

Table-I: Key terms used for literature search.

\begin{tabular}{l|c|c|c}
\hline Keywords & Pub Med & ERIC & Psycinfo \\
\hline Flipped Classroom & 1194 & 842 & 13 \\
\hline Procedural Skills & 15643 & 823 & 223 \\
\hline Postgraduate Trainees & 5634 & 106 & 259 \\
\hline Boolean Operators & 133 & 7 & 3 \\
\hline $\begin{array}{l}\text { Flipped classroom and } \\
\text { Procedural skills }\end{array}$ & 23 & 0 & 1 \\
\hline $\begin{array}{l}\text { Flipped classroom and } \\
\text { Procedural skills and } \\
\text { Postgraduate trainees }\end{array}$ & & & \\
\hline
\end{tabular}

in Canada, 1 each in Pakistan and India respectively. Different methods were utilized for pre-class activities including power point presentations, VLE, Simulation based or real time videos of procedures with accompanying reading material. The adobe connect learning systems was most commonly used for pre-class activities which encompasses all of the technology 
necessary to realize FC project. It allows live streaming of lecturers with variety of windows including live video and the ability to see the instructors as they speak. They also can view the instructor's desktop or
Power Point presentation at the same time and interact utilizing combinations of a variety of pods, both the instructor and the learner could manipulate the learning environment to their best uses ${ }^{17}$.

Table-II: Critical appraisal of relevant studies.

\begin{tabular}{|c|c|c|c|c|}
\hline Year/Journal/ Country/Title & Design \& Objective & Sample & Data collection & Key findings \\
\hline $\begin{array}{l}\text { USA }^{8} \\
\text { J Grad Med Educ. } \\
2019 \\
\text { Effects of a Flipped Classroom } \\
\text { Curriculum on Inpatient Cardiology } \\
\text { Resident Education }\end{array}$ & $\begin{array}{l}\text { Quasi-experimental } \\
\text { To prove that a FC of Medical } \\
\text { Knowledge Self-Assessment } \\
\text { Program could improve } \\
\text { resident knowledge and } \\
\text { preparedness in cardiology. }\end{array}$ & $\begin{array}{l}37 \text { in } \\
\text { each } \\
\text { group }\end{array}$ & $\begin{array}{l}\text { 20MKSAP } \\
\text { question scores } \\
\text { and 5-point Likert } \\
\text { scales for } \\
\text { preparedness }\end{array}$ & $\begin{array}{l}\text { Flipped classroom } \\
\text { did not affect } \\
\text { knowledge and } \\
\text { preparedness when } \\
\text { compared to usual } \\
\text { teaching. Residents } \\
\text { expressed high } \\
\text { satisfaction. }\end{array}$ \\
\hline $\begin{array}{l}\text { USA }^{9} \\
\text { J Grad Med Educ. } \\
2017 \\
\text { Results of a Flipped Classroom } \\
\text { Teaching Approach in } \\
\text { Anesthesiology Residents }\end{array}$ & $\begin{array}{l}\text { Prospective, controlled, } \\
\text { multicenter, educational } \\
\text { research study } \\
\text { To prove that a FC improves } \\
\text { knowledge acquisition and } \\
\text { retention for residents } \\
\text { compared to traditional lecture }\end{array}$ & $\begin{array}{c}142 \\
(\mathrm{n}=83 \\
\text { flipped } \\
\text { class; } \\
\mathrm{n}=59 \\
\text { lecture })\end{array}$ & $\begin{array}{l}\text { Primary outcome - } \\
\text { knowledge } \\
\text { acquisition and } \\
\text { retention- scores in } \\
\text { MCQs. Secondary } \\
\text { outcome - resident } \\
\text { attitudes surveys }\end{array}$ & $\begin{array}{l}\text { Anesthesiology } \\
\text { residents' preference } \\
\text { for the flipped } \\
\text { classroom and a } \\
\text { beneficial effect of } \\
\text { this teaching method } \\
\text { on knowledge } \\
\text { retention. } \\
\end{array}$ \\
\hline $\begin{array}{l}\text { Canada } 10 \\
\text { BMC Medical Education } \\
2015 \\
\text { Flipping for success: evaluating the } \\
\text { effectiveness of a novel teaching } \\
\text { approach in a graduate level setting }\end{array}$ & $\begin{array}{c}\text { Quantitative Survey } \\
\text { To analyze FC affectivity with: } \\
\text { 1) socio-demographics, 2) exam } \\
\text { grades, 3) student satisfaction, } \\
\text { 4) course effectiveness. }\end{array}$ & $\begin{array}{l}67 \\
\text { Masters- } \\
\text { level } \\
\text { graduate } \\
\text { students }\end{array}$ & $\begin{array}{l}\text { Likert scale } \\
\text { Surveys, open } \\
\text { ended questions, } \\
\text { Peer evaluation } \\
\text { report, quiz, SEEQ. }\end{array}$ & $\begin{array}{l}\text { FC provided better } \\
\text { opportunities for } \\
\text { students to nurture } \\
\text { critical thinking, } \\
\text { independent } \\
\text { learning, and peer } \\
\text { learning. }\end{array}$ \\
\hline $\begin{array}{l}\text { USA }^{11} \\
\text { Ochsner Journal } \\
2016 \\
\text { Using the Flipped Classroom to } \\
\text { Bridge the Gap to Generation Y }\end{array}$ & $\begin{array}{l}\text { Quantitative-Interventional } \\
\text { To find out if the FC model } \\
\text { translate into better } \\
\text { performance in examinations }\end{array}$ & $\begin{array}{c}70 \\
\text { students }\end{array}$ & $\begin{array}{l}\text { Scores in MCQs } \\
\text { and OSCE }\end{array}$ & $\begin{array}{c}\text { A statistically } \\
\text { significant increase in } \\
\text { scores on the MCQs } \\
\text { and OSCE was seen } \\
\text { in students taught by } \\
\text { FC. }\end{array}$ \\
\hline $\begin{array}{l}\text { USA }^{12} \\
\text { The Clinical Teacher } \\
2015 \\
\text { The flipped classroom for medical } \\
\text { students }\end{array}$ & $\begin{array}{l}\text { Mixed method } \\
\text { To implement a FC curriculum } \\
\text { for the obstetrics and gynae } \\
\text { clerkship, and to find out } \\
\text { student satisfaction with it. }\end{array}$ & $\begin{array}{c}89 \\
\text { students }\end{array}$ & $\begin{array}{l}\text { Validated } \\
\text { satisfaction survey, } \\
\text { scores of pre and } \\
\text { post-test }\end{array}$ & $\begin{array}{c}\text { Student were very } \\
\text { satisfied with both } \\
\text { phases of curriculum. } \\
\text { There was no } \\
\text { significant difference } \\
\text { in final student } \\
\text { grades post } \\
\text { intervention } \\
\end{array}$ \\
\hline $\begin{array}{l}\text { India }{ }^{13} \\
\text { Korean Journal of Medical } \\
\text { Education } \\
2016 \\
\text { Flipped clinical training: a } \\
\text { structured training method for } \\
\text { undergraduates in complete denture } \\
\text { prosthesis }\end{array}$ & $\begin{array}{c}\text { Analytical type of } \\
\text { observational study } \\
\text { To use FC training in } \\
\text { removable complete denture } \\
\text { treatment and find out } \\
\text { itseffectiveness by comparing } \\
\text { assessment results against } \\
\text { those taught by traditional } \\
\text { methods }\end{array}$ & $\begin{array}{c}181 \\
\text { students. }\end{array}$ & Checklist scores & $\begin{array}{l}\text { The number of } \\
\text { students } \\
\text { demonstrating } \\
\text { competency in } \\
\text { complete denture } \\
\text { treatment was more } \\
\text { for FC. }\end{array}$ \\
\hline $\begin{array}{l}\text { USA }^{14} \\
\text { WestJEM } \\
2014 \\
\text { The Flipped Classroom: A Modality } \\
\text { for Mixed Asynchronous and } \\
\text { Synchronous Learning in a } \\
\text { Residency Program }\end{array}$ & $\begin{array}{l}\text { Mixed method } \\
\text { To learn about resident and } \\
\text { faculty impressions of FC } \\
\text { sessions. }\end{array}$ & $\begin{array}{l}\quad 35 \\
\text { residents }\end{array}$ & $\begin{array}{l}4 \text { point Likert } \\
\text { scale. } \\
\text { Open-ended } \\
\text { questions }\end{array}$ & $\begin{array}{l}\text { Residents } \\
\text { appreciated the } \\
\text { flipped model. They } \\
\text { preferred a small } \\
\text { group size. }\end{array}$ \\
\hline
\end{tabular}




\begin{tabular}{|c|c|c|c|c|}
\hline $\begin{array}{l}\text { USA }^{15} \\
\text { J Am Acad Dermatol } \\
2011 \\
\text { Procedural dermatology training } \\
\text { during dermatology residency: A } \\
\text { survey of third-year dermatology } \\
\text { residents }\end{array}$ & $\begin{array}{l}\text { Quantitative Survey } \\
\text { To assess the third-year resident } \\
\text { experience in procedural } \\
\text { dermatology during residency } \\
\text { training. }\end{array}$ & $\begin{array}{l}240 \\
\text { residents }\end{array}$ & $\begin{array}{c}\text { Survey } \\
\text { questionnaire }\end{array}$ & $\begin{array}{l}55 \% \text { were very } \\
\text { satisfied with their } \\
\text { procedural training } \\
\text { during residency. }\end{array}$ \\
\hline $\begin{array}{l}\text { USA }^{16} \\
\text { Advances in Medical Education } \\
\text { and Practice } \\
2017 \\
\text { Flipped classroom model for } \\
\text { learning evidence-based medicine }\end{array}$ & $\begin{array}{c}\text { Observational } \\
\text { Topresent the flow of learning } \\
\text { activities in flipped EBM } \\
\text { classroom and highlight specific } \\
\text { considerations for implementing } \\
\text { a flipped classroom model. }\end{array}$ & 14 & $\begin{array}{l}\text { Questions } \\
\text { regarding validity } \\
\text { and results of } \\
\text { study }\end{array}$ & $\begin{array}{l}\text { Implementing a FC } \\
\text { model to teach EBM } \\
\text { improves learning } \\
\text { opportunities for } \\
\text { students }\end{array}$ \\
\hline $\begin{array}{l}\text { United States } 17 \\
\text { Frontiers in Neurology } \\
2017 \\
\text { Randomized Control study of a } \\
\text { remote flipped classroom of neuro- } \\
\text { otology curriculum. }\end{array}$ & $\begin{array}{l}\text { Randomized Control trial } \\
\text { To test the hypothesis that } \\
\text { learning in on-line class will } \\
\text { produce similar outcomes to } \\
\text { traditional classroom based on } \\
\text { FC approach }\end{array}$ & 274 & $\begin{array}{l}\text { Scores of pretest } \\
\text { and posttest. }\end{array}$ & $\begin{array}{l}\text { The use of FC } \\
\text { demonstrated similar } \\
\text { results to the } \\
\text { traditional one. }\end{array}$ \\
\hline $\begin{array}{l}\text { United States } 6 \\
\text { JAAD } \\
2019 \\
\text { A video-based, flipped classroom, } \\
\text { simulation curriculum for } \\
\text { dermatologic surgery: A } \\
\text { prospective, multi-institution study }\end{array}$ & $\begin{array}{l}\text { Prospective multi institutional } \\
\text { study } \\
\text { To assess the impact of video } \\
\text { education and surgical } \\
\text { simulation on dermatology } \\
\text { resident procedural skills. }\end{array}$ & 31 & $\begin{array}{l}\text { OSATs scores } \\
\text { Surveys }\end{array}$ & $\begin{array}{l}\text { Video education and } \\
\text { simulation are } \\
\text { effective for } \\
\text { improving } \\
\text { dermatology residents' } \\
\text { procedural skills. }\end{array}$ \\
\hline $\begin{array}{l}\text { USA }^{18} \\
\text { Education for health } \\
2017 \\
\text { Teaching Procedural Skills to } \\
\text { Medical Students:A Pilot } \\
\text { Procedural Skills Lab } \\
\end{array}$ & $\begin{array}{l}\text { Cross-sectional Quantitative } \\
\text { To check the effect of a } \\
\text { multifaceted Procedural Skills } \\
\text { Lab on the improvement in } \\
\text { confidence of medical students } \\
\text { performing the procedures. }\end{array}$ & 106 & $\begin{array}{c}\text { Student's } \\
\text { confidence level } \\
\text { Likert scale }\end{array}$ & $\begin{array}{c}\text { A strategically } \\
\text { improvised } \\
\text { Procedural skill } \\
\text { increases students' } \\
\text { confidence to perform } \\
\text { procedural skills. } \\
\end{array}$ \\
\hline $\begin{array}{l}\text { USA }{ }^{19} \\
\text { JCEHP } \\
2016 \\
\text { Flipping the Continuing Medical } \\
\text { Education Classroom: Validating a } \\
\text { Measure of Attendees' Perceptions. }\end{array}$ & $\begin{array}{l}\text { Cross-sectional validation study. } \\
\text { To develop and validate an } \\
\text { instrument measuring flipped } \\
\text { classroom perceptions of the } \\
\text { students experiencing the } \\
\text { intervention. }\end{array}$ & 167 & $\begin{array}{c}\text { A flipped } \\
\text { classroom } \\
\text { perception } \\
\text { instrument (FCPI) } \\
\text { with Likert scale }\end{array}$ & $\begin{array}{l}\text { The FCPI has good } \\
\text { validity evidence. }\end{array}$ \\
\hline $\begin{array}{l}\text { USA }{ }^{20} \\
\text { J EducEval Health Prof } \\
2016 \\
\text { Flipping the ACLS classroom with } \\
\text { TBL: comparison of cognitive } \\
\text { testing performance for medical } \\
\text { students at the University of } \\
\text { California,, United State }\end{array}$ & $\begin{array}{l}\text { Quasi-experimental pre-posttest. } \\
\text { To find if written test scores } \\
\text { improved for ACLS taught in } \\
\text { flipped classroom/team-based } \\
\text { Learning (FC/TBL) vs. lecture- } \\
\text { based (LB) traditional control. }\end{array}$ & 354 & $\begin{array}{l}\text { MCQs, rhythm } \\
\text { matching, fill-in } \\
\text { clinical cases. }\end{array}$ & $\begin{array}{l}\text { A FC/TBL format for } \\
\text { ACLS marginally } \\
\text { improved written test } \\
\text { scores. }\end{array}$ \\
\hline
\end{tabular}

Short quiz submission after pre-class activity was a common method used by teachers to commit their students in the activity. Multiple choice questions, OSCEs, OSPEs, OSTEs, Peer evaluation reports and marks given for presentations were the instruments used for assessing students' performance of procedural skills after FC. As for learning strategies in the in-class stage, the most frequently adopted strategies were peer-peer or facilitator guided discussion, guided practicing of skills, and problem-based learning. Most stu- dies mainly focused on imparting and assessing knowledge, skills and to a lesser extent attitude training, while focus on learners' higher order thinking skills was lacking. POGIL-Process oriented guided inquiry learning activity and SICKO online decision making games were novel in-class activities used in 2 studies 22,24 .

Application of FCs in medical education has grown rapidly over the past decade, with the number 
growing dramatically from 7 papers in 2014, to 16 papers in 2015, and 22 papers in $2016^{31}$.

\section{DISCUSSION}

Study results revealed 10 best practices for its use in skill training i.e. dedicated educational time, standardized general format, topic-based clinical modules, multiple instructional methods, good-quality video pre-class material, accountability in preparation of preclass material, use of practice questions, case-based learning, simulation-based skills trainingand dedicated staff and faculty leader ${ }^{22}$. Going through pre-class material helps in priming with background knowledge for carrying out the in-class task ${ }^{32}$. FC for complete denture prosthesis was used as a structured training method for undergraduates ${ }^{13}$. It's role in the changing landscape of anesthesia training was researched ${ }^{33}$. In gynaeobstetrics clerkship FC was used successfully in gynae oncology module and was also assessed in another study by OSCE showing better results than control group ${ }^{11,12}$. It's role in ophthalmology clerkship, emergency medicine clerk-ship, evidence based medicine in residency, renal pharmacology module, foundation of anatomy module and procedural skill lab in undergraduate studentshas revealed promising result $16,21,24,23,18,34$, It has been used successfully in procedural skill cadaveric laboratory for sonography scan, echocardiogram, lumbar puncture, arthrocentesis, and insertion of intraosseous and intravenous catheters ${ }^{35}$. Flipped structured training program for complete dental prosthesis shifted learning from clinics to learning centers (phase1) and preserved practice in clinics (phase 2) in Sri-Rama Chandra University ${ }^{13}$. Flipping the ACLS classroom with team-based learning also showed encouraging results in University of California, USA ${ }^{20}$. Reviews of surgical students from Stanford University were overwhel-mingly positive when simulation-based FC for surgical clerk-ship was introduced ${ }^{22}$. There are many procedural skills involved in dermatology residency and flipped learning has recently being introduced for improving the efficiency of training ${ }^{15}$. Introduction of a flipped dermatology module in an undergraduate setting gained positive reviews from students ${ }^{27}$. Similarly, Duke University Medical Center Flipped curriculum was introduced and received positively by dermatology residents ${ }^{28}$. Even in Pakistan it has been used for dermatology residents and assessed by OSCE and MCQs. Student perception were recorded by FCPI ${ }^{30}$.

Perceptions about FC intervention were recorded using different survey questionnaires with Likert sca- les, open-ended questions in these studies. However the only validated instrument and hence the best was FC perception instrument (FCPI) which was developed and validatedby Dr. Christopher R. Stephenson and his team. Four major topics addressed were pre-class activity, in-class learning, active learning techniques and collaborative learning. After repetitive revisiting and subsequent improvements, finally eight items were selected with responses on five point Likert scale. Factor analysis was carried out for individual items for establishing internal structure validity. Internal consistency reliability values for items comprising each factor and overall were calculated with the Cronbach a ( $a$ $>0.7$ was considered acceptable) ${ }^{19}$. This instrument was successfully utilized in Mayo clinic Quality improvement curriculum in $2015^{25}$. In a study carried out in dermatology residents in Pakistan it was again successfully used after 2 FCs for dermatology procedures with few open-ended questions, after permission from the original author and establishing reliability ${ }^{30}$.

The format of the FC provide opportunities for students promoting critical thinking, student-centered learning, and promoting academically beneficial peer interactive learning. Facilitators also enjoy flexibility in chunking of study material, provision of in-class problem-solving activities and offering timely constructive feedback to students ${ }^{10}$. Pre-class study material appeared to be viewed easily by most students in a multitude of environments ${ }^{36}$. It allows to put more responsibility of learning on students who then strive to work towards mastery of subject and improving their skills as per $21^{\text {st }}$ century health care needs. Cost-effectiveness of courses and meeting the demands of ever increasing number of students in institutes with economic restraints is also an added benefit. Going through the pre-class material decreases the students anxiety and makes them more confident in class, Re-enforcement and better retention of important points along with preference for small group discussions in in-class sessions were results of another study based on the usage of this modality combining synchronous and asynchronous learning ${ }^{14}$. Hence if planning and responsibility for this pedagogical approach is done successfully, it improves students participation, satisfaction and performance at all levels ${ }^{37}$. Flipped learning model requires effective faculty development programs before implementation ${ }^{33}$. Many students in different studies have given negative reviews about the workload of the delivered pre-class content and the number of assignments. Flexibility in content acquisition has also been considered as a double edged sword by being fruitful 
for students with good self-regulatory skills and promoting procrastination in poor time managers ${ }^{38}$. Also the quality of discussion during interactive sessions is dependent on student's preparation ${ }^{14}$. Limitation of technology can also negatively impact the students experiences with flipped learning like many of them report poor audiovisual quality, long duration and inability to give feedback about the quality of videos in different studies ${ }^{10}$. Studies have also shown that FC can only be effectively used when content material is concrete and not abstract ${ }^{21}$. A study carried out in our settings on dermatology residents revealed FC as resource intensive, time demanding and useless for unmotivated students. Students recommended improving videos, making them short and concise and giving more time to students for pre-class activity ${ }^{30}$.

\section{CONCLUSION}

Flipped learning can bring dramatic improvement if strategically applied based on structured training program having defined objectives. It can be adopted as an effective teaching strategy of procedural skills to residents in all fields including dermatology. It can increase the flexibility of curriculum to curtail the demands in face of COVID-19 pandemic.

\section{CONFLICT OF INTEREST}

This study has no conflict of interest to be declared by any author.

\section{REFERENCES}

1. Yousaf MJ, Yasmeen R, Khan MA, Qamar K. Preceptions of Postgraduate residents regarding clinical educational environment by using the post graduate hospital education environment measure (PHEEM) inventory. Pak Arm For Med J 2017; 67(6): 914-18.

2. Zulfiqar K; MUR. Challenges faced by female doctors during fellowship training hindering their professional progress in a conservative cultural context. Pak Arm For Med J 2018; 68(2): 310-15.

3. Kim MK, Kim SM, Khera O, Getman J. The experience of three flipped classrooms in an urban university: An exploration of design principles. Internet High Educ 2014; 22(2018): 37-50.

4. Abeysekera L, Dawson P. Motivation and cognitive load in the flipped classroom: definition, rationale and a call for research. High Educ Res Dev 2015; 34(1): 1-14.

5. Karaca C, Ocak MA. Effect of flipped learning on cognitive load: a higher education research. J Learn Teach Digit Age 2017; 2(1): 20-27.

6. Liu KJ, Tkachenko E, Waldman A, Boskovski MT, Hartman RI, Levin AA, et al. A video-based, flipped classroom, simulation curriculum for dermatologic surgery: A prospective, multi-institution study. J Am Acad Dermatol 2019; 81(6): 1271-76.

7. Kmet LM, Lee RC, Cook LS. Standard quality assessment criteria for evaluating primary reseach papers from a variety of fields. 2004 [Internet] Available from: https://www.biomedcentral. com/content/supplementary/1471-2393-14-52-s2.pdf (assessed at: 2018, Sep 16)
8. Allenbaugh J, Spagnoletti C, Berlacher K. Effects of a flipped classroom curriculum on inpatient cardiology resident education. J Grad Med Educ 2019; 11(2): 196-201.

9. Martinelli SM, Chen F, DiLorenzo AN, Mayer DC, Fairbanks S, Moran K, et al. Results of a flipped classroom teaching approach in anesthesiology residents. J Grad Med Educ 2017; 9(4): 485-90.

10. Moraros J, Islam A, Yu S, Banow R, Schindelka B. Flipping for success: evaluating the effectiveness of a novel teaching approach in a graduate level setting. BMC Med Educ 2015; 15(1): 27-30.

11. Gillispie V. Using the flipped classroom to bridge the gap to Generation Y. Ochsner J 2016; 16(1): 32-36.

12. Morgan H, Mclean K, Chapman C, Fitzgerald J, Yousuf A, Hammoud $\mathrm{M}$. The $\mathrm{fl}$ ipped classroom for medical students. Clin Teach 2015; 12(12): 155-60.

13. Anbarasi K, Mohammed KK, Vijayaraghavan P, Kandaswamy D. Flipped clinical training: a structured training method for undergraduates in complete denture prosthesis. Korean J Med Educ 2016; 28(4): 333-42.

14. Young T, Bailey C, Guptill M, Thorp A, Thomas T. The flipped classroom: a modality for mixed asynchronous and synchronous learning in a residency program. West J Emerg Med 2014; 15(7): 938-44.

15. Lee EH, Nehal KS, Dusza SW, Hale EK, Levine VJ. Procedural dermatology training during dermatology residency: A survey of third-year dermatology residents. J Am Acad Dermatol 2011; 64(3): 475-83.

16. Rucker SY, Ozdogan Z, Al Achkar M. Flipped classroom model for learning evidence-based medicine. Adv Med Educ Pract 2017; $8(1): 619-25$

17. Carrick FR, Abdulrahman M, Hankir A, Zayaruzny M, Najem K, Lungchukiet $\mathrm{P}$, et al. Randomized controlled study of a remote flipped classroom neuro-otology curriculum. Front Neurol 2017; 8(7): 1-10.

18. Katz LM, Finch A, Mckinnish T, Gilliland K, Tolleson-rinehart S, Marks BL. Teaching procedural skills to medical students: a pilot procedural skills lab 2017; 30(1): 79-83.

19. Stephenson CR, Wang AT, Szostek JH, Bonnes SL, Ratelle JT, Mahapatra S, et al. Flipping the continuing medical education classroom. J Contin Educ Health Prof 2016; 36(4): 256-62.

20. Boysen-osborn M, Anderson CL, Navarro R, Yanuck J, Strom S, Mccoy CE, et al. Flipping the advanced cardiac life support classroom with team- based learning: comparison of cognitive testing performance for medical students at the University of California , Irvine, United State. J Educ Eval Health Prof 2016; 13(1): 11-30.

21. Tang F, Chen C, Zhu Y, Zuo C, Zhong Y, Wang N, et al. Comparison between flipped classroom and lecture-based classroom in ophthalmology clerkship. Med Educ Online 2017; 22(1): 139567988.

22. Liebert CA, Mazer L, Bereknyei Merrell S, Lin DT, Lau JN. Student perceptions of a simulation-based flipped classroom for the surgery clerkship: A mixed-methods study. Surg 2016; 160(3): 591-98.

23. Morton DA, Colbert-Getz JM. Measuring the impact of the flipped anatomy classroom: The importance of categorizing an assessment by Bloom's taxonomy. Anat Sci Educ 2017; 10(2): 170-75.

24. Pierce R, Fox J. Vodcasts and active-learning exercises in a "flipped classroom" model of a renal pharmacotherapy module. Am J Pharm Educ 2012; 76(10): 196-98.

25. Bonnes SL, Ratelle JT, Halvorsen AJ, Carter KJ, Hafdahl LT, Wang AT, et al. Flipping the Quality Improvement Classroom in Residency Education. Acad Med 2017; 92(1): 101-107.

26. Strom S, Anderson C, Yang L, Canales C, Amin A, Lotfipour S, et al. Correlation of Simulation Examination to Written Test Scores 
for Advanced Cardiac Life Support Testing: Prospective Cohort Study. West J Emerg Med 2015; 16(6): 907-12.

27. Fox J, Faber D, Pikarsky S, Zhang C, Riley R, Mechaber A, et al. Development of a Flipped Medical School Dermatology Module. South Med J 2017; 110(5): 319-24.

28. Pontius LN,Hooten J, Lesesky E, Rao C, Nicholas M, Bialas R, et al. Comparison of knowledge acquisition and perceived efficacy of a traditional vs flipped classroom-based dermatology residency curriculum. Cutis 2020; 105(01): 36-39.

29. Chokshi BD, Schumacher HK, Reese K, Bhansali P, Kern JR, Simmens SJ, et al. Resident-as-teacher; curriculum using a flipped classroom approach: can a model designed for efficiency also be effective. Academic Medicine 2017: 92(4); 511-14.

30. Malik SS, Yasmeen R, Khan R. A Randomized controlled study to evaluate the effect of flipped classroom relative to a traditional demonstration method on learning of procedural skills in dermatology residents. J Pak Med Assoc 2020; 70(9): 1547-53.

31. Lin HC, Hwang GJ. Research trends of flipped classroom studies for medical courses: a review of journal publications from 2008 to 2017 based on the technology-enhanced learning model. Interact
Learn Environ 2019; 27(8): 1011-27.

32. Crothers AJ, Bagg J, Mckenzie R. The Flipped Classroom for preclinical dental skills teaching-a reflective commentary. Nat Publ Gr 2017; 222(9): 709-13.

33. Kurup V, Hersey D. The changing landscape of anesthesia education. Curr Opin Anaesthesiol 2013; 26(6): 726-31.

34. Lew EK. Creating a contemporary clerkship curriculum: the flipped classroom model in emergency medicine. Lew Int J Emerg Med 2016; 9(1): 25-28.

35. Katz LM, Finch A, McKinnish T, Gilliland K, Tolleson-Rinehart S, Marks BL. Teaching procedural skills to medical students: A pilot procedural skills lab. Educ Health 2017; 30(1): 79-83.

36. Newman G, Kim JH, Lee RJ, Brown BA, Huston S. The perceived effects of flipped teaching on knowledge acquisition background and literature review. J Eff Teach 2016; 16(161): 52-71.

37. Uzunboylu H, Karagozlu D. Flipped classroom: A review of recent literature. World J Educ Technol 2015; 7(2): 142-45.

38. McLean S, Attardi SM, Faden L, Goldszmidt M. Flipped classrooms and student learning: not just surface gains. Adv Physiol Educ 2016; 40(1): 47-55. 